\title{
Obtaining of $\mathrm{Fe}_{3} \mathrm{O}_{4} @ \mathrm{C}$ Core-Shell Nanoparticles as an Adsorbent of Tetracycline in Aqueous Solutions
}

\author{
Vivian Soares ${ }^{a}$, Ana Flávia dos Santos de Moraes ${ }^{c}$, Janaína dos Santos ${ }^{c}$, Marina Carla Grando ${ }^{c}$, \\ Cleuzir da Luz ${ }^{d}$, Gustavo Lopes Colpani ${ }^{b}$, Luciano Luiz Silva ${ }^{b}$, Márcio Antônio Fiori, ${ }^{a, b *}$ (৫, \\ Josiane Maria Muneron de Mello ${ }^{a, b}$
}

${ }^{a}$ Programa de Pós-Graduação em Ciências Ambientais, Universidade Comunitária da Região de Chapecó - Unochapecó, Chapecó, SC, Brasil

${ }^{b}$ Programa de Pós-Graduação em Tecnologia e Gestão da Inovação, Universidade Comunitária da Região de Chapecó - Unochapecó, Chapecó, SC, Brasil

${ }^{c}$ Curso de Graduação em Engenharia Química, Universidade Comunitária da Região de Chapecó Unochapecó, Chapecó, SC, Brasil

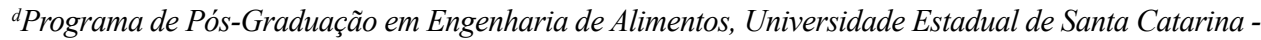
UDESC, Pinhalzinho, SC, Brasil

Received: December 17, 2018; Revised: June 10, 2019; Accepted: July 16, 2019

Tetracycline is used to treat various diseases in animals and humans, so its high use causes this substance to be frequently found in effluents and in potable water reservoirs, causing serious problems for human health and the environment. Many processes are applied and evaluated in an attempt to removal tetracycline found in environment, such as adsorption. The application of iron-carbon nanoparticles with core-shell structure $\left(\mathrm{Fe}_{3} \mathrm{O}_{4} @ \mathrm{C}\right)$ as adsorbent, can be an alternative to removal of these contaminants. In the present study $\mathrm{Fe}_{3} \mathrm{O}_{4} @ \mathrm{C}$ nanoparticles were synthesized and used to adsorb tetracycline in aqueous solutions. The core-shell characterization was performed using X-ray diffraction techniques, infrared spectroscopy, surface area, chemical analysis and morphology, and adsorption capacity through isotherms. The results indicated that $\mathrm{Fe}_{3} \mathrm{O}_{4} @ \mathrm{C}$ nanoparticles presented good tetracycline removal capability, $73.3 \%$, when applied an initial concentration of antibiotic of the $30 \mathrm{mg} \mathrm{L}^{-1}$ and $0.5 \mathrm{~g}$ of adsorbent.

Keywords: Core-shell nanoparticles, adsorption, tetracycline, magnetite nanoparticles.

\section{Introduction}

Antibiotics are widely used in the treatment of diseases in animals and humans, as well as applied in food rations in order to increase animal growth rates ${ }^{1,2}$. Among the most commonly used antibiotics are tetracyclines ${ }^{3}$, which has high antimicrobial activity associated it's the aromatic structure that containing the naphthol chemical group that is antibacterial ${ }^{4}$. However, approximately $50-90 \%$ of the doses of tetracyclines administered in health treatment procedures are not absorbed by organisms and are eliminated by humans and animals in sewage systems ${ }^{5-7}$. Tetracycline molecules have a complex chemical structure and the natural environmental and sewage conditions are not sufficient to decompose their chemical structure. Thus, the amount of tetracycline accumulated in sewage can be a serious environmental problem ${ }^{8}$.

Physical-pharmacological and biological methods have been used to remove the drugs from aqueous mediums. But recently new techniques have been evaluated for this propose, such as adsorption, membrane filtration, photocatalysis, ozonization and electroxidation ${ }^{9-11}$. However, these processes generally generate toxic secondary compounds and have low removal efficiency in short time periods and are costly $y^{4,12}$.

*e-mail: marciofiori@gmail.com.
Consequently, the presence of these drugs and their secondary compounds in water or sewage systems ${ }^{13,14}$ contributes to the natural selection of bacteria that are resistant to antibiotics ${ }^{15-17}$.

Among the methods of removal of tetracycline, the adsorption is a process fast, economical and low energy cost process, and does not form secondary compounds ${ }^{18-21}$. Adsorption is widely applied in environmental treatment applications around the world. Liquid-solid adsorption systems are based on the ability of certain solids to preferentially concentrate specific substances from solutions onto their surfaces ${ }^{22}$.

In this sense, the magnetic nanoparticles, composed of a core of magnetite and by a nanolayer of carbon have shown unique characteristics for application in adsorption processes $^{23}$. Nanoparticles with magnetic properties can be efficiently separated from wastewater by using magnetic separators, avoiding the filtration process, which represents a difficulty in using nanosized materials at the treatment of great volumes of wastewaters in environmental remediation processes $^{24,25}$. This core-shell nanostructure associates the high adsorption capability of the carbon nanoparticles with the high number of active sites and high magnetic response, which provides a fast and efficient separation of nanoparticles ${ }^{26,27}$. In addition, protects the core of carbon acids and alkaline environments, avoiding your deterioration ${ }^{28,29}$. 
In this work, core-shell nanoparticles, magnetite covered by the carbon $\left(\mathrm{Fe}_{3} \mathrm{O}_{4} @ \mathrm{C}\right)$, were obtained through hydrothermal process. These nanoparticles were physical and chemical characterized and their absorption capacity of tetracycline molecules was evaluated.

\section{Experimental Procedure}

\subsection{Synthesis of $\mathrm{Fe}_{3} \mathrm{O}_{4} @ \mathrm{C}$ nanoparticles}

Core-shell nanoparticles $\left(\mathrm{Fe}_{3} \mathrm{O}_{4} @ \mathrm{C}\right)$ were obtained using the methodology applied by Lima et al. ${ }^{30}$. In $250 \mathrm{~mL}$ of distilled water was added $11.26 \mathrm{~g}$ of glucose (97.5\% purity - $\mathrm{C}_{6} \mathrm{H}_{12} \mathrm{O}_{6}$ - Merck), $37.54 \mathrm{~g}$ of urea (99\% purity $-\mathrm{CH}_{4} \mathrm{~N}_{2} \mathrm{O}-$ Vetec) and $15.15 \mathrm{~g}$ of iron (III) nitrate $\left(99 \%\right.$ purity $-\mathrm{Fe}\left(\mathrm{NO}_{3}\right)_{3} \cdot 9 \mathrm{H}_{2} \mathrm{O}-$ Merck). After 15 min of agitation in a magnetic system $3.12 \mathrm{~g}$ of propylene glycol PEG 1500 (Dinâmica) was added and mixed by 5 min.

The new solution was transferred to a stainless steel (AISI 3014) reactor coated by Teflon with a volume of 200 $\mathrm{mL}$. The reactor was closed and heated in a drying oven (Nova Ética, $402 / 3 \mathrm{~N}$ model) at $180^{\circ} \mathrm{C}$ during $18 \mathrm{~h}$. The solution was then removed from the reactor and cooled until room temperature. After this process the solution was washed three times with distilled water and washed two times with ethanol (99\% purity; $\mathrm{C}_{2} \mathrm{H}_{5} \mathrm{OH}$; Vetec). Finally, the nanoparticles were oven dried by $2 \mathrm{~h}$ at $70{ }^{\circ} \mathrm{C}$.

\subsection{Characterization of nanoparticles, $\mathrm{Fe}_{3} \mathrm{O}_{4} @ \mathrm{C}$}

Nanoparticles of $\mathrm{Fe}_{3} \mathrm{O}_{4} @ \mathrm{C}$ was characterized by x-ray diffraction (XRD), Fourier transform infrared (FT-IR), Brunauer-Emmett-Teller (BET), scanning electron microscopy (SEM/FEG) and energy dispersive spectroscopy (EDS).

$\mathrm{X}$-ray diffraction analysis was made using a $\mathrm{X}$-ray powder diffraction diffractometer (Bruker, model D8) with $\mathrm{CuK} \alpha$ radiation target $(\lambda=1.5418 \AA$ ) , electrical tension of $40 \mathrm{kV}$, electrical current of $40 \mathrm{~mA}$, wavelength with steps of 0.02 , exposure time per step of 1 second and 2 Theta angle range from $2^{\circ}$ to $72^{\circ}$. The Rietveld refinement method was used for the identification of phases and the chemical composition, determination of the type of crystalline structure. The size of the crystallites was determined using the Scherrer equation with $\mathrm{k}=0.94^{31}$.

FTIR analysis was performed with a Fourier transform infrared spectrophotometer (Jasco, FTIR 4200 model) with wavenumber range between 400 to $4000 \mathrm{~cm}^{-1}$. The samples were previously prepared in a disk format mixing $5 \mathrm{mg}$ of nanoparticles and $300 \mathrm{mg}$ of potassium bromide (KBr).

Specific surface area of the core-shell nanoparticles was determined by Brunauer-Emmett-Teller - BET methods $^{32}$ (ASTM D 6556-17 $7^{33}$ ), using a static nitrogen adsorption instrument (Quantachrome, model Autosorb 1C). The diameter and volume of pores were calculated using the Barret, Joyner e Halenda (BJH) methods.
The samples were pretreated at $100{ }^{\circ} \mathrm{C}$ under vacuum conditions ( $10^{-7}$ Torr) by $3 \mathrm{~h}$. For determine the density and the volume of the core-shell nanoparticles the gas pycnometer equipment (Quantachrome, Ultrapycnometer 1200 e model) was used.

The core-shell morphology and the its surface chemical composition were analyzed using a scanning electron microscope (SEM-FEG, Tescan, Czech Republic, Mira $3-20 \mathrm{kV}$ ) and an energy dispersive spectrometer (EDS), respectively.

\subsection{Determination of the zero-charge point $\left(\mathrm{pH}_{P C Z}\right)$}

Zero-charge point $\left(\mathrm{pH}_{\mathrm{PCZ}}\right)$ of nanoparticles $\mathrm{Fe}_{3} \mathrm{O}_{4} @ \mathrm{C}$ was determined according method described for Babic et al. ${ }^{34}$ and Regalbuto and Robles ${ }^{35}$, with modifications. The experiments were conducted in $50 \mathrm{~mL}$ of ultrapure water in Erlenmeyer flasks with volume of $125 \mathrm{~mL}$, The initial $\mathrm{pH}$ values of all solutions were adjusted using a solution of $\mathrm{NaOH} 0.1 \mathrm{~N}$ (99\% purity, Vetec) or a solution of $\mathrm{HCl} 0.1 \mathrm{~N}(99 \%$ purity, Vetec), with values between 1 and 12. The $\mathrm{pH}$ values were measured with a pHmeter (Bel Engineering ${ }^{\circledR}, \mathrm{W} 3 \mathrm{~B}$ ). After that, $0.1 \mathrm{~g}$ of core-shell nanoparticles was added in each solution. The flasks were placed on shaker (Logen Scientific, LS 4500 ) at $100 \mathrm{rpm}$ and $25^{\circ} \mathrm{C}$ by $24 \mathrm{~h}$. Subsequently, the solutions were filtrated through with membranes with pores diameter of $0.22 \mu \mathrm{m}$ (Merck) and the final $\mathrm{pH}$ values were measured again.

\subsection{Adsorption kinetics}

Adsorption kinetic tests were performed in Erlenmeyers with $100 \mathrm{~mL}$ of a solution of tetracycline with concentration of $30 \mathrm{mg} \mathrm{L}^{-1}$ (Fragon, purity 98.6\%) and with $0.5 \mathrm{~g}$ of core-shell nanoparticles. The adsorption experiments were conducted at $25^{\circ} \mathrm{C}$, pH 5.0 and on a shaker at $100 \mathrm{rpm}$.

Aliquots from the solutions were centrifuged at $3400 \mathrm{rpm}$ by $10 \mathrm{~min}$ and then filtered using a membrane with diameter pore of $0.2 \mu \mathrm{m}$ with the aid of a vacuum pump and then the passant solution were analyzed in the UV-Vis spectrophotometer (SpectraMax, Plus 384) in the wavelengths range between 250 and $550 \mathrm{~nm}$. The characteristic absorber band for the tetracycline aqueous solution was identified at wavelength of 357 $\mathrm{nm}$. All solutions were analyzed using quartz cuvettes and performed in triplicate.

A calibration curve to determine the tetracycline concentrations in the solutions were obtained with the UVVisible spectrophotometer preparing solutions with different concentrations of tetracycline in distilled water, varying from 3 to $30 \mathrm{mg} \mathrm{L}^{-1}$. For each concentration, the respective absorbance value in $357 \mathrm{~nm}$ was obtained and associated with the respectively concentration. A plot associating the absorbance values with the tetracycline concentration was obtained and defined as the calibration curve. 
Experimental data were compared to the kinetic models of pseudo-first order and pseudo-second order to determine the kinetic parameters, according to Equations (01) and (02) respectively. The intraparticle diffusion model also available which presented in Equation (03).

$$
\begin{aligned}
\frac{d q_{t}}{d t} & =k_{1}\left(q_{e}-q_{t}\right) \\
\frac{d q_{t}}{d t} & =k_{2}\left(q_{e}-q_{t}\right)^{2} \\
q_{t} & =k_{i n} \cdot t^{\frac{1}{2}}+C
\end{aligned}
$$

Where $q_{t}\left(\mathrm{mg} \mathrm{g}^{-1}\right)$ is the amount of tetracycline in the solid phase of time; $t(\mathrm{~min})$ is the time of adsorption; $q_{e}$ $\left(\mathrm{mg} \mathrm{g}^{-1}\right)$ é $\mathrm{a}$ is the amount of tetracycline at the equilibrium; $\mathrm{k}_{1}\left(\mathrm{~min}^{-1}\right)$ is the first-order rate constant; $\mathrm{k}_{2}\left(\mathrm{mg} \mathrm{g}^{-1} \mathrm{~min}^{-1}\right)$ is the second-order rate constant; $\mathrm{k}_{\text {in }}\left(\mathrm{mg} \mathrm{g}^{-1} \mathrm{~min}^{-1 / 2}\right)$ is the intraparticle diffusion rate constant; $\mathrm{C}\left(\mathrm{mg} \mathrm{g}^{-1}\right)$ is a constant related to the diffusion resistance.

The amount of tetracycline adsorbed at equilibrium was calculated by Equation (04).

$$
q_{e}=\frac{V\left(C_{o}-C_{e}\right)}{m}
$$

Where: $q_{e}\left(\mathrm{mg} \mathrm{g}^{-1}\right)$ is the adsorption capacity at the equilibrium; $\mathrm{V}(\mathrm{L})$ is the volume of the tetracycline solution, $\mathrm{C}_{0}\left(\mathrm{mg} \mathrm{L}^{-1}\right)$ is the initial concentration of tetracycline in the solution, $\mathrm{C}\left(\mathrm{mg} \mathrm{L}^{-1}\right)$ the concentration of tetracycline at equilibrium and $\mathrm{m}(\mathrm{g})$ is the mass of the nanoparticles.

The kinetic parameters of the models evaluated are determined using Statistica ${ }^{\circledR} 7.0$ (StatSoft $^{\mathbb{\circledR}}$, USA). The Quasi-Newton method was applied to minimize the square sum of errors (SSE), which is calculated using Equation (5). $q_{e x p}$ and $q_{c a l}$ are the experimental and calculated adsorption capacity, respectively.

$$
S S E=\sum_{i}^{p}\left(q_{e r p}-q_{c a l}\right)
$$

\subsection{Adsorption isotherms}

For the adsorption isotherm studies the flasks samples containing the solutions were agitated in the shaker at $100 \mathrm{rpm}$ during $4 \mathrm{~h}$ (defined in preliminary tests). The solutions were prepared with $100 \mathrm{~mL}$ of a tetracycline solution with $30 \mathrm{mg}$ $\mathrm{L}^{-1}$ and containing different mass of core-shell nanoparticles, between 0.1 and $0.9 \mathrm{~g}$. The $\mathrm{pH}$ values of all solutions were adjusted at 5.0 using a solution of $\mathrm{HCl} 0.1 \mathrm{M}$ (Vetec-purity de $99 \%$ ). Subsequently, the flask samples were centrifuged at $3400 \mathrm{rpm}$ (FANEM ${ }^{\circledR}$, Excelsa II 206BL) by $10 \mathrm{~min}$ and filtered using the membrane with pore diameter of $0.2 \mu \mathrm{m}$ and aided of a vacuum pump and then analyzed in the UV-Visible spectrophotometer using the characteristic wavelength in $357 \mathrm{~nm}$.
The respective concentration values of the tetracycline in all solutions were determined comparing the absorbance values with the calibration curve. The isotherms were performed at three temperatures, being $25^{\circ} \mathrm{C}, 35^{\circ} \mathrm{C}$ and $45^{\circ} \mathrm{C}$ and all experiments were conducted in triplicates.

In order to describe the interactive behavior between solute and adsorbent, the Langmuir, Freundlich e LangmuirFreundlich models were applied to analyze the equilibrium adsorption characteristics, according with the Equation (06), (07) and (08), respectively.

$$
\begin{gathered}
q_{e}=\frac{q_{\max } b_{L} C_{e}}{1+b_{L} C_{e}} \\
q_{e}=k_{F} C_{e^{\frac{1}{n F}}}^{\frac{1}{n_{F}}} \\
q_{e}=\frac{q_{m L F}\left(b_{L F} C_{e}\right)^{m_{L F}}}{1+\left(b_{L F} C_{e}\right)^{m+F}}
\end{gathered}
$$

Where $q_{e}\left(\mathrm{mg} \mathrm{g}^{-1}\right)$ is the amount of tetracycline adsorbed at equilibrium on the core-shell nanoparticles; $C_{e}\left(\mathrm{mg} \mathrm{L}^{-1}\right)$ is the concentration of tetracycline in the liquid phase at equilibrium; $b_{L}\left(\mathrm{~L} \mathrm{mg}^{-1}\right)$ is the Langmuir adsorption equilibrium that represents surface affinity; $q_{\max }\left(\mathrm{mg} \mathrm{g}^{-1}\right)$ is the amount of tetracycline adsorbed at saturation; $k_{f}$ and $n_{f}$ are the parameters of Freundlich models, where $n_{f}$ provides an indication whether the isotherm is favorable or unfavorable. Values of $n_{f}$ in the range between 1 to 10 represent favorable adsorption conditions; $m_{L F}$ is LangmuirFreundlich constant; $q_{m L F}\left(\mathrm{mg} \mathrm{g}^{-1}\right)$ is the maximum coverage capacity of the monolayer and $b_{L F}\left(\mathrm{~L} \mathrm{mg}^{-1}\right)$ is the affinity parameter Langmuir-Freundlich.

The isotherms parameters of the proposed models were found using the Statistica ${ }^{\circledR} 7.0$ (StatSoft ${ }^{\circledR}$, USA). The Quasi-Newton method was applied to minimize the square sum of errors (SSE), which is calculated using Equation (5).

The thermodynamic parameters were calculated by constructing the $\operatorname{lnK}$ plot as a function of $\mathrm{T}^{-1}$ in $\mathrm{K}$. The equation of the better adjusted line was generated and the thermodynamic parameters calculated, in which the enthalpy and entropy variation were obtained from the slope and the intersection of the line. The equations used to calculate the constant $\mathrm{K}$ (Herny constant) and to calculate the parameters, Van't Hoff equation, are expressed in Equations (09), (10) and (11), respectively.

$$
\begin{gathered}
q_{e}=k \cdot C_{e} \\
\ln K=\frac{-\Delta H}{R T}+\frac{\Delta S}{R} \\
\Delta G=\Delta H-T \Delta S
\end{gathered}
$$




\section{Results and Discussion}

\subsection{Characterization of nanoparticles}

Figure 1 shows the morphology of the $\mathrm{Fe}_{3} \mathrm{O}_{4} @ \mathrm{C}$ structures. It is possible to observe that the nanoparticles formed have a spherical geometry, with diameters ranging from 30 to 70 $\mathrm{nm}$, as well as tend to form agglomerates with dimensions of approximately $200 \mathrm{~nm}$ to $400 \mathrm{~nm}$. The formation of these aggregate structures is an indicator that the surface energy of the nanoparticles is relatively strong. The results obtained resemble those described by Zhang et al. ${ }^{36}$ and Fini, Niasari and Ghanbari ${ }^{37}$.

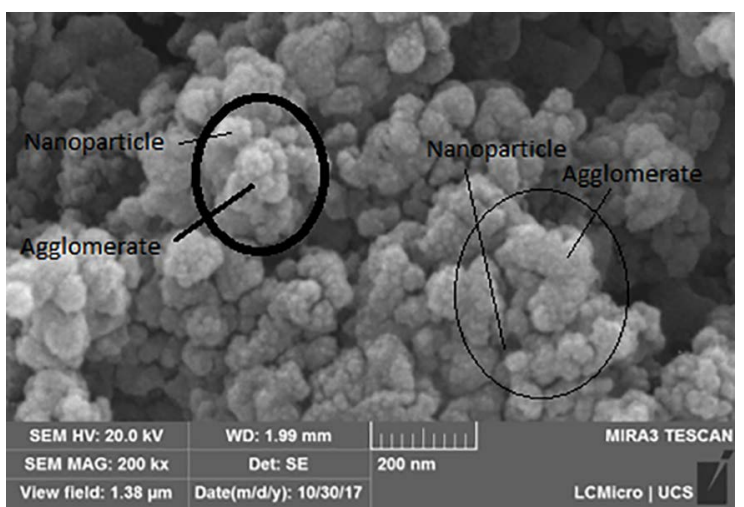

Figure 1. SEM images obtained with $\mathrm{Fe}_{3} \mathrm{O}_{4} @ \mathrm{C}$ nanoparticles.

The spectrum obtained by EDS and the chemical maps, shown in Figure 2, reveal the presence of iron, carbon and oxygen elements. The elemental maps show a uniform distribution of these elements in the nanostructures, which may characterize the formation of magnetite cores covered with carbon. Similar results were obtained by Rostami-Vartooni, Moradi-Saadatmand and $\mathrm{Mahdavi}^{38}$ and Zarei, Niad and Raanaei ${ }^{39}$, that synthesized carbon/ $\mathrm{Fe}_{3} \mathrm{O}_{4}$ nanocomposite and $\mathrm{Fe}_{3} \mathrm{O}_{4}$-nanocellulose compounds, respectively, and observed similar characteristics.

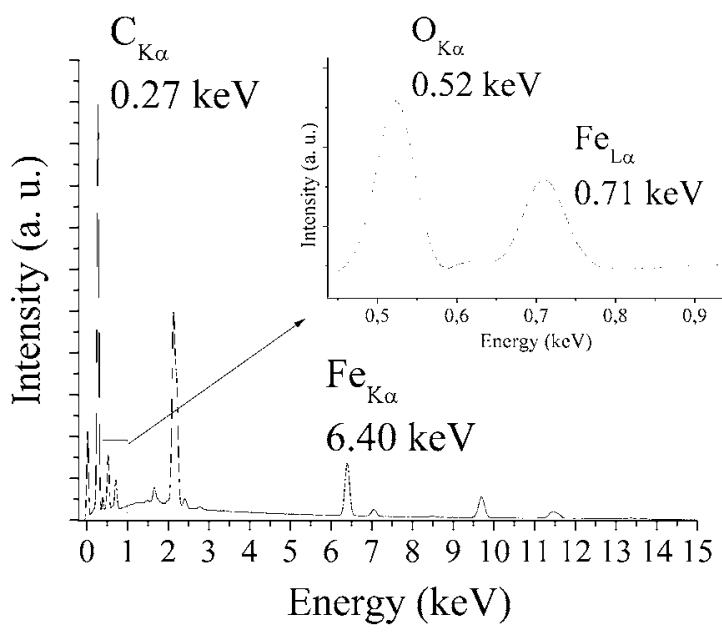

Figure 2. EDS spectra obtained with $\mathrm{Fe}_{3} \mathrm{O}_{4} @ \mathrm{C}$ nanoparticles.
Figure 3 shows the $x$-ray diffractogram obtained for the $\mathrm{Fe}_{3} \mathrm{O}_{4} @ \mathrm{C}$. The peaks detected in the x-ray diffractogram in $18.3^{\circ}, 30.1^{\circ}, 35.4^{\circ}, 37.0^{\circ}, 43.0^{\circ}, 53.6^{\circ}, 56.9^{\circ}$ and $62.5^{\circ}$ are associated to the crystalline planes (111), (220), (311), (222), (400), (422), (511) and (440) of the magnetite (0-45. $^{4}$. The magnetite is a magnetic iron oxide phase originated from chemical reaction between the iron specimens and the glucose molecule in the reactor and is covered by the carbon of the core-shell nanoparticle. The peak inherent to carbon predicted at approximately $26^{\circ} 45$ was not clearly defined in the diffractogram possibly to the low concentration in relation to the nucleus of $\mathrm{Fe}_{3} \mathrm{O}_{4}$ (magnetite).

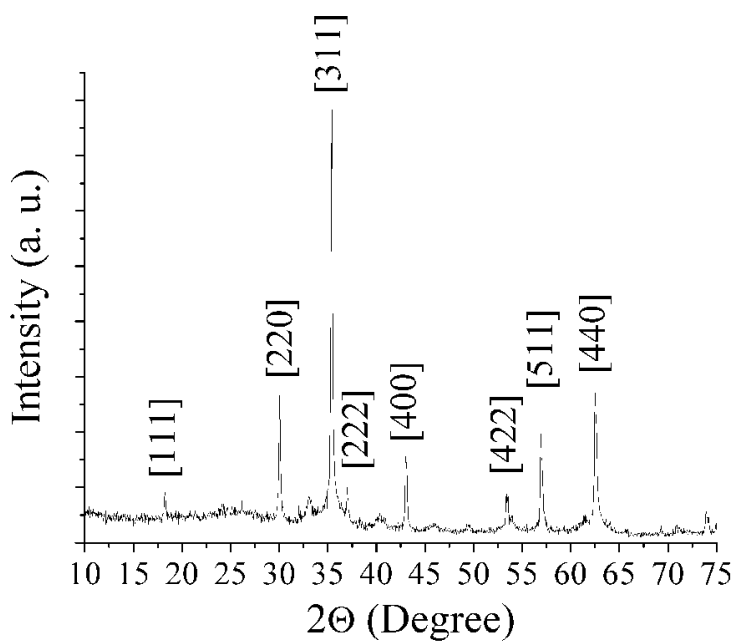

Figure 3. XRD diffractogram obtained with $\mathrm{Fe}_{3} \mathrm{O}_{4} @ \mathrm{C}$ nanoparticles. $\mathrm{Fe}_{3} \mathrm{O}_{4}$ : COD 96-900-9770 and C: COD 96-101-1061.

Table 1 shows the Rietveld refinement for the x-ray diffractogram results for the core-shell nanoparticles. The results demonstrated the presence of carbon and magnetite in greater quantity, as expected. The lattice parameters determined for the unit cell of the magnetite and carbon phases was similar to those observed in literature, unit cell parameters: $\mathrm{a}=\mathrm{b}=2.47 \AA$ and $\mathrm{c}=$ $6.79 \AA$ for the crystalline carbon phase and $\mathrm{a}=\mathrm{b}=\mathrm{c}=8.38$ $\AA$ for the magnetite phase $\mathrm{e}^{46-48}$. The Scherrer method was applied considering the spherical crystallite form for the core-shell nanoparticles $(k=0.94)$ and the average values determined for the magnetite crystallite size were $69.33 \mathrm{~nm}$, similar to the size values observed by scanning electron microscopes.

Information about the Functional groups on the surface of the core-shell nanoparticles $\mathrm{Fe}_{3} \mathrm{O}_{4} @ \mathrm{C}$ was obtained with FT-IR, according Figure 4. The FT-IR analysis performed shows the presence of an absorption band at $561 \mathrm{~cm}^{-1}$, which identify the Fe-O vibrational bond ${ }^{49}$, confirming the presence of iron oxide in the structure. In addition, the presence of carbon can be verified by the absorption bands in $1260 \mathrm{~cm}^{-1}, 1590 \mathrm{~cm}^{-1}$ and $2920 \mathrm{~cm}^{-1}$, associated with the chemical groups $\mathrm{C}-\mathrm{O}^{50}, \mathrm{C}-\mathrm{C}^{51}$ and $\mathrm{C}-\mathrm{H}^{52}$, respectively. 
Table 1. Results of Rietveld analysis of $\mathrm{Fe}_{3} \mathrm{O}_{4} @ \mathrm{C}$ nanoparticles.

\begin{tabular}{lcccccc}
\hline Sample & Phase & Crystalline Strucuture & Content $(\mathrm{wt} \%)$ & Unit cell Parameters $(\AA)$ & Particle size $(\mathrm{nm})$ & $\chi^{2}$ \\
\hline \multirow{2}{*}{$\mathrm{Fe}_{3} \mathrm{O}_{4} @ \mathrm{C}$} & $\mathrm{C}$ & Tetragonal & 2.8 & $\mathrm{a}=\mathrm{b}=2.47$ & $\mathrm{c}=6.79$ & 69.33 \\
& & & & $\mathrm{c}=6.6$ & \\
& $\mathrm{Fe}_{3} \mathrm{O}_{4}$ & Cubic & 97.2 & $\mathrm{a}=\mathrm{b}=\mathrm{c}=8.38$ & \\
\hline
\end{tabular}

* XRD pattern: monocristaline silicon.

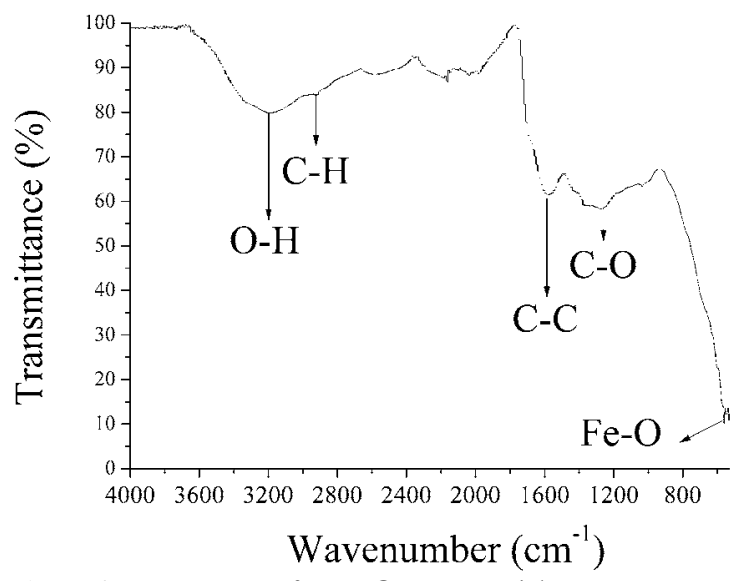

Figure 4. FTIR spectra of $\mathrm{Fe}_{3} \mathrm{O}_{4} @ \mathrm{C}$ nanoparticles.

The bands located at $3250 \mathrm{~cm}^{-1}$ can be attributed to the hydroxyl group or water hydrogen ${ }^{53}$, from the glucose or propylene glycol used in the synthesis of the nanoparticles or from the water molecules adsorbed on the nanoparticles of $\mathrm{Fe}_{3} \mathrm{O}_{4} @ \mathrm{C}$.

Surface area value of the core-shell nanoparticles was measured using the BET method and the value determined was $63.37 \mathrm{~m}^{2} \mathrm{~g}^{-1}$. The average values of the pore volume $\left(0.19 \mathrm{~cm}^{3} \mathrm{~g}^{-1}\right)$ and pore size $(8.99 \mathrm{~nm})$ were determined using the mathematical model BJH with the results of BET. The surface porosity of the core-shell nanoparticles is representative of a mesoporous structure and is possibly related with the spaces formed between the agglomerates of the nanoparticles, since their value is high in relation to the dimensions of the nanoparticles. These values and characteristics are similar to those found by Zhong et al. ${ }^{54}$ and Sayahi et al. ${ }^{55}$ in studies with graphene@magnetite@ carbon nanosheets and magnetite/graphite nanocomposites, respectively.

\subsection{Point of zero-charge $\left(\mathrm{pH}_{P C Z}\right)$}

Figure 5 presents the $\mathrm{pH}$ chart end of an aqueous solution as a function of $\mathrm{pH}$. Intersection point of the resulting curve with the line passing origin $\left(\mathrm{pH}_{\text {final }}=\mathrm{pH}_{\text {initial }}\right)$ is defined as the $\mathrm{pH}_{\mathrm{PZC}}{ }^{56}$.

For the $\mathrm{Fe}_{3} \mathrm{O}_{4} @ \mathrm{C}$ nanoparticles, it is noted that the zerocharge point is approximately 5.0. It can be said that the surface of $\mathrm{Fe}_{3} \mathrm{O}_{4} @ \mathrm{C}$ nanoparticles has a positive charge with $\mathrm{pH}$ values lower than 5.0, preferentially adsorbing anionic compounds, and negative charge with $\mathrm{pH}$ values higher than 5.0, preferentially adsorbing cationic compounds $\mathrm{s}^{57}$.

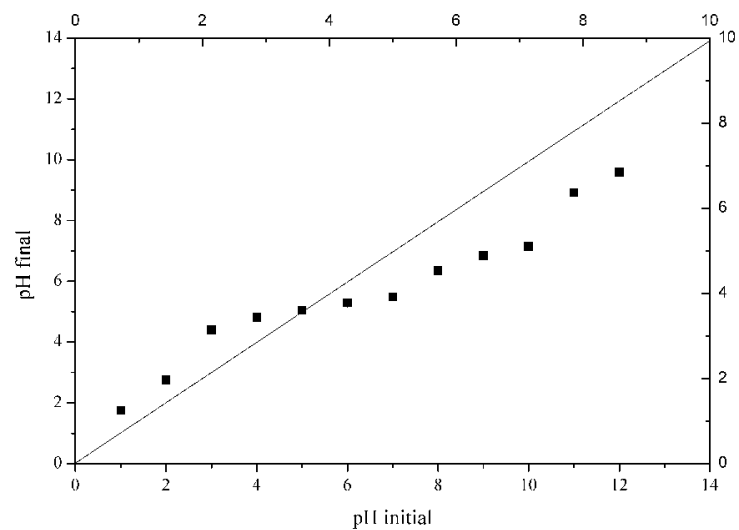

Figure 5. Determination of $\mathrm{pH}_{\mathrm{PZC}}(\mathrm{pH}$ initial value; $\mathrm{pH}$ final value).

At $\mathrm{pH}=5$, used in kinetic and isothermal tests, tetracycline behaves as a zwitterion (dipole ion), possessing positive and negative charges, the latter being those that led to an adsorption on the surface of $\mathrm{Fe}_{3} \mathrm{O}_{4} @ \mathrm{C}$ nanoparticles ${ }^{58}$.

\subsection{Adsorption kinetics}

Figure 6 shows the adsorption kinetics results for the adsorptions of the tetracycline with a concentration of $30 \mathrm{mg} \mathrm{L}^{-1}$ in aqueous medium by a mass of $0.5 \mathrm{~g}$ of $\mathrm{Fe}_{3} \mathrm{O}_{4} @ \mathrm{C}$ nanoparticles. It's possible to observe a significant decrease of the concentrations of tetracycline concentration in the aqueous medium during the first 50 min, removing approximately $58 \%$. The high adsorption rate of the tetracycline molecules is possibly due to the higher tetracycline concentration gradient between the liquid phase (aqueous medium) and the solid phase (adsorbent) in this first time period of the process and also because that the adsorption is controlled by diffusion mechanisms on the surface of the adsorbent. The first diffusion mechanism is fast, because the diffusion processes occur on the boundary layer, followed by the diffusion processes of the adsorbate (tetracycline) into the pores and capillaries of the adsorbent structure (core-shell nanoparticles), thus, it corresponds to the intraparticle adsorption where the velocity is lower ${ }^{59-61}$.

It can be observed in the Figure 6, the concentration remaining in the liquid phase, after the balance to the adsorption process, was approximately $8 \mathrm{mg} \mathrm{L}^{-1}$, in a time of 140 minutes. Therefore, for conditions of $\mathrm{pH} 5.0$ and temperature of $25{ }^{\circ} \mathrm{C}$ the tetracycline concentration of $30 \mathrm{mg} \mathrm{L}^{-1}$ and adsorbent mass of $0.5 \mathrm{~g}$, the removal was approximately $73 \%$. 
This high adsorption efficiency can be ascribed to abundant unoccupied active sites on the surface of the core-shell adsorbent and the high tetracycline concentration gradient in the initial stage, as well as the high specific surface area of core-shell nanoparticles ${ }^{62}$. In a study developed by Jafari et al. ${ }^{63}$ in which the authors used activated carbon-coated $\mathrm{Fe}_{3} \mathrm{O}_{4}$ nanoparticles, $\mathrm{AC} @ \mathrm{Fe}_{3} \mathrm{O}_{4}$, as adsorbent to adsorb tetracycline, reached equilibrium in approximately 60 minutes, using a concentration of $20 \mathrm{mg} \mathrm{L}^{-1}$ tetracycline. The removal efficiency determined by the author was of approximately $50 \%$, below the efficiency found in the present work.

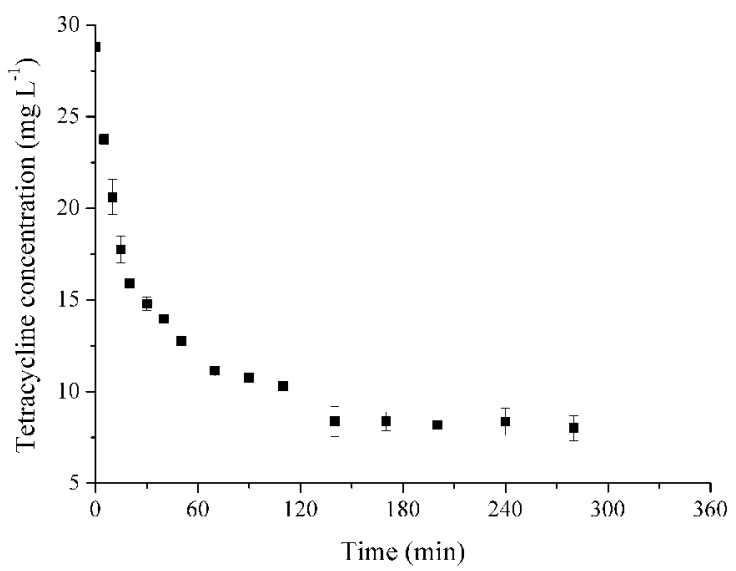

Figure 6. Kinetics of adsorption of tetracycline by $\mathrm{Fe}_{3} \mathrm{O}_{4} @ \mathrm{C}$ nanoparticles. Initial concentration of $30 \mathrm{mg} \mathrm{L}^{-1}$ and $0.5 \mathrm{~g}$ of nanoparticles

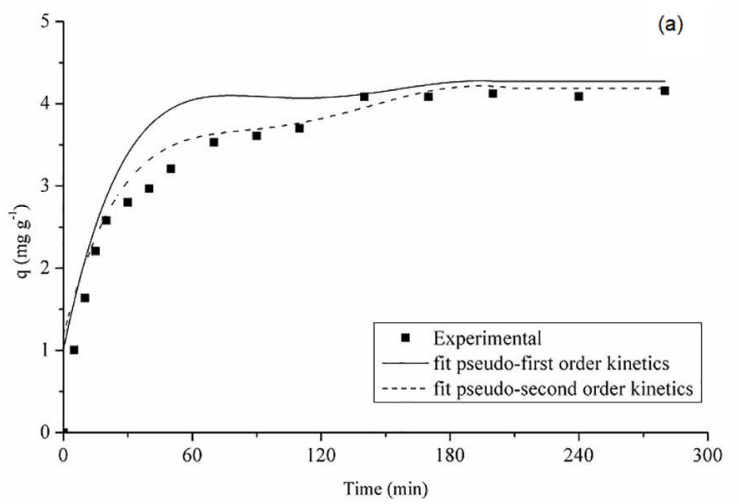

To identify the mechanisms involved in the adsorption process, kinetic experimental results were fitted with kinetic models of pseudo-first order, pseudo-second order and intraparticle diffusion. The results of the adjustments, as well as the experimental results, are presented in Figure 7 (a) and (b).

The Table 2 shows the values for adsorption kinetic constants, determined from the application of the pseudofirst order, pseudo-second order and intraparticle diffusion model, for the tetracycline adsorption processes by the core-shell nanoparticles. In this table also presented the correlation coefficient of determination $\left(\mathrm{R}^{2}\right)$ for each model. The correlation coefficient is a good indicator of the good adjust of a theorical kinetic models and the highest value was established as the best fit. In addition to the values of $\mathrm{R}^{2}$, were also compared the values of the concentration of tetracycline adsorbed at equilibrium determined by experiments $\left(\mathrm{q}_{\mathrm{e}(\exp )}\right)$ and the correspondent concentrations determined from the adjustments of the theoretical kinetic models, Table 3 . The value of the theoretical must be the closest to the value of $\mathrm{q}_{\mathrm{e}(\exp )}$. Thus, the adsorption of the tetracycline molecules by the core-shell nanoparticles occurs according to the pseudofirst order or pseudo-second order model.

According the $\mathrm{R}^{2}$ values (Table 2), the model that best represents the tetracycline adsorption process by $\mathrm{Fe}_{3} \mathrm{O}_{4} @ \mathrm{C}$ nanoparticles is the kinetic model of pseudo-second order. Analyzing the results presented in the Table 4, it's possible to observe smallest deviation between the values of $\mathrm{q}_{\mathrm{e}(\exp )}$ and $\mathrm{q}_{\mathrm{e}(\text { (alc) }}$, for the pseudo-second order model.

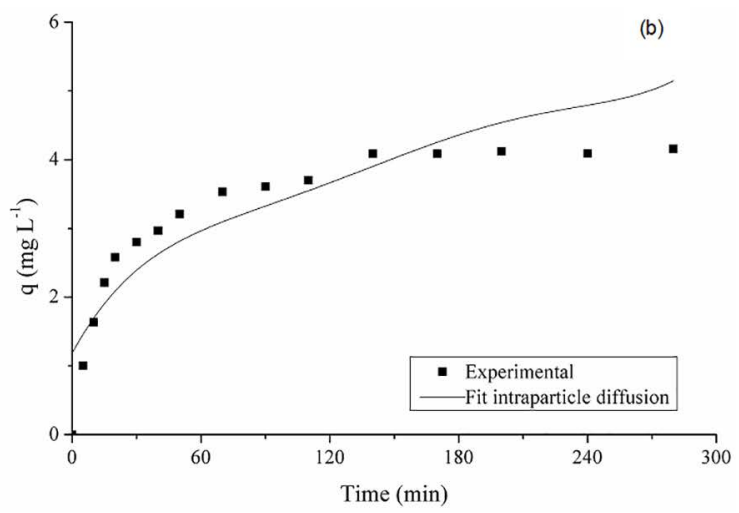

Figure 7. Experimental results of tetracycline adsorbed on the adsorbent as a function of time and adjust for models of pseudo-first order, the pseudo-second order (a) and the intraparticle diffusion (b)

Table 2. Kinetic parameters of the kinetic model of pseudo-first order, pseudo-second order and intraparticle diffusion for tetracycline.

\begin{tabular}{lccc}
\hline Parameters & Pseudo-first order & Pseudo-second order & Intraparticle diffusion \\
\hline $\mathrm{k}_{1}\left(\mathrm{~min}^{-1}\right)$ & 0.0396 & - & - \\
$\mathrm{k}_{2}\left(\mathrm{~g} \mathrm{mg}^{-1} \mathrm{~min}^{-1}\right)$ & - & 0.0126 & - \\
$\mathrm{C}\left(\mathrm{mg} \mathrm{g}^{-1}\right)$ & - & - & 0.2467 \\
$\mathrm{k}_{\text {in }}\left(\mathrm{mg} \mathrm{g}^{-1} \mathrm{~min}^{-1 / 2}\right)$ & - & - & 1.0102 \\
$\mathrm{R}^{2}$ & 0.877 & 0.952 & 0.852 \\
\hline
\end{tabular}


Table 3. Concentration of equilibrium in the determined solid phase, applying the pseudo-first-order model, pseudo-second order, obtained experimentally.

\begin{tabular}{|c|c|c|c|c|}
\hline Kinects Model & $\mathrm{q}_{\mathrm{e}(\exp )}\left(\mathrm{mg} \mathrm{g}^{-1}\right)$ & $\mathrm{q}_{\mathrm{e} \text { (calc) }}\left(\mathrm{mg} \mathrm{g}^{-1}\right)$ & Deviation (\%) & $\mathrm{R}^{2}$ \\
\hline pseudo- $1^{\mathrm{a}}$ order & 4.1594 & 4.1998 & 0.0097 & 0.877 \\
\hline pseudo- $2^{\mathrm{a}}$ order & 4.1594 & 4.1198 & 0.0095 & 0.952 \\
\hline
\end{tabular}

Table 4. Adsorption isotherm parameters of the Langmuir, Freundlich and Langmuir-Freundlich models for temperatures of $25^{\circ} \mathrm{C}, 35^{\circ} \mathrm{C}$ and $45^{\circ} \mathrm{C}$.

\begin{tabular}{|c|c|c|c|c|c|c|}
\hline Temperature & Langmuir & Freundlich & Langmuir-Freundlich & & & \\
\hline \multirow{4}{*}{$\begin{array}{l}\circlearrowright \\
\stackrel{2}{\sim}\end{array}$} & $\mathrm{q}_{\max }\left(\mathrm{mg} \mathrm{g}^{-1}\right)$ & 7.610 & $\mathrm{n}_{\mathrm{f}}$ & 2.623 & $\mathrm{q}_{\mathrm{mLF}}\left(\mathrm{mg} \mathrm{g}^{-1}\right)$ & 14.734 \\
\hline & $\mathrm{b}_{\mathrm{L}}\left(\mathrm{L} \mathrm{g}^{-1}\right)$ & 0.173 & $\mathrm{k}_{\mathrm{f}}$ & 1.924 & $\mathrm{~b}_{\mathrm{LF}}\left(\mathrm{L} \mathrm{g}^{-1}\right)$ & 0.025 \\
\hline & $\mathrm{R}_{\mathrm{L}}$ & 0.162 & & & $\mathrm{~m}_{\mathrm{LF}}$ & 0.554 \\
\hline & $\mathrm{R}^{2}$ & 0.955 & $\mathrm{R}^{2}$ & 0.989 & $\mathrm{R}^{2}$ & 0.986 \\
\hline \multirow{4}{*}{$\begin{array}{l}\text { O } \\
\text { in }\end{array}$} & $\mathrm{q}_{\max }\left(\mathrm{mg} \mathrm{g}^{-1}\right)$ & 5.478 & $\mathrm{n}_{\mathrm{f}}$ & 2.419 & $\mathrm{q}_{\mathrm{mLF}}\left(\mathrm{mg} \mathrm{g}^{-1}\right)$ & 5.603 \\
\hline & $b_{L}\left(L^{-1}\right)$ & 0.099 & $\mathrm{k}_{\mathrm{f}}$ & 1.049 & $\mathrm{~b}_{\mathrm{LF}}\left(\mathrm{L} \mathrm{g}^{-1}\right)$ & 0.096 \\
\hline & $\mathrm{R}_{\mathrm{L}}$ & 0.252 & & & $\mathrm{~m}_{\mathrm{LF}}$ & 0.909 \\
\hline & $\mathrm{R}^{2}$ & 0.902 & $\mathrm{R}^{2}$ & 0.921 & $\mathrm{R}^{2}$ & 0.895 \\
\hline \multirow{4}{*}{$\begin{array}{l}0 \\
\text { in } \\
\stackrel{f}{*}\end{array}$} & $\mathrm{q}_{\max }\left(\mathrm{mg} \mathrm{g}^{-1}\right)$ & 3.765 & $\mathrm{n}_{\mathrm{f}}$ & 2.463 & $\mathrm{q}_{\mathrm{mLF}}\left(\mathrm{mg} \mathrm{g}^{-1}\right)$ & 3.391 \\
\hline & $\mathrm{b}_{\mathrm{L}}\left(\mathrm{L} \mathrm{g}^{-1}\right)$ & 0.079 & $\mathrm{k}_{\mathrm{f}}$ & 0.680 & $\mathrm{~b}_{\mathrm{LF}}\left(\mathrm{L} \mathrm{g}^{-1}\right)$ & 0.100 \\
\hline & $\mathrm{R}_{\mathrm{L}}$ & 0.296 & & & $\mathrm{~m}_{\mathrm{LF}}$ & 1.096 \\
\hline & $\mathrm{R}^{2}$ & 0.788 & $\mathrm{R}^{2}$ & 0.824 & $\mathrm{R}^{2}$ & 0.777 \\
\hline
\end{tabular}

This means that the rate of adsorption is directly proportional to the square of the tetracycline concentration. For different adsorbents, several authors showed the success of the application of the pseudo-second order model for the representation of kinetic data for tetracycline adsorption ${ }^{64,65,62}$.

The kinetic model of pseudo-second order, predicts the behavior during the entire adsorption time, and indicates that the adsorption process can be occurs from a possible formation of complexes on the surface of the nanoparticles, probably occurring due to the ionic pairing mechanism. The study by Jafari et al. ${ }^{63}$ evaluated the adsorption mechanism of tetracycline using $\mathrm{Fe}_{3} \mathrm{O}_{4}$ nanoparticles coated with activated carbon, and obtained that the dominant mechanism was also pseudo-second order. The authors related that the adsorption process involves the exchange or sharing of electrons between tetracycline and nanoparticles. The study by Liu et al. ${ }^{65}$ found a range for the pseudo-second order model of $0.0139 \mathrm{~g} \mathrm{mg}^{-1} \mathrm{~min}^{-1}$ using MCM-41 impregnated with zeolite to adsorb tetracycline at $50 \mathrm{mg} \mathrm{L}^{-1}$ concentration. The value obtained by the authors is close to that found in this study.

\subsection{Adsorption isotherms}

Adsorption isotherms for the tetracycline adsorption processes were performed to evaluate the equilibrium relationship between the $\mathrm{Fe}_{3} \mathrm{O}_{4} @ \mathrm{C}$ nanoparticles concentration and the tetracycline concentration in the aqueous medium phase at constant temperature. Figures 8, 9 and 10 show the adsorption isotherms obtained from the experimental data at different temperatures: $25^{\circ} \mathrm{C}, 35^{\circ} \mathrm{C}$ and $45^{\circ} \mathrm{C}$, respectively, as well the respectively curves obtained for the adjustment of the theorical models of Langmuir, Freundlich and Langmuir-Freundlich models.

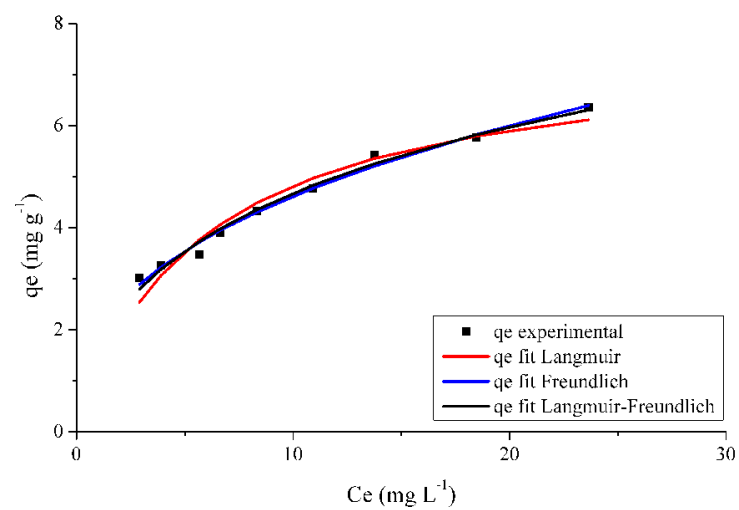

Figure 8. Experimental and predicted adsorption isotherms for tetracycline for the Langmuir, Freundlich and Langmuir-Freundlich models, at temperature of de $25^{\circ} \mathrm{C}$.

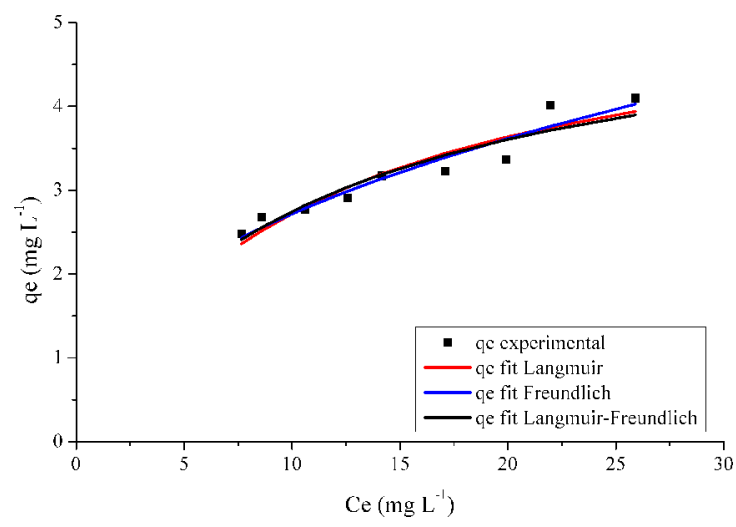

Figure 9. Experimental and predicted adsorption isotherms for tetracycline for the Langmuir, Freundlich and Langmuir-Freundlich models, at temperature of $35^{\circ} \mathrm{C}$. 


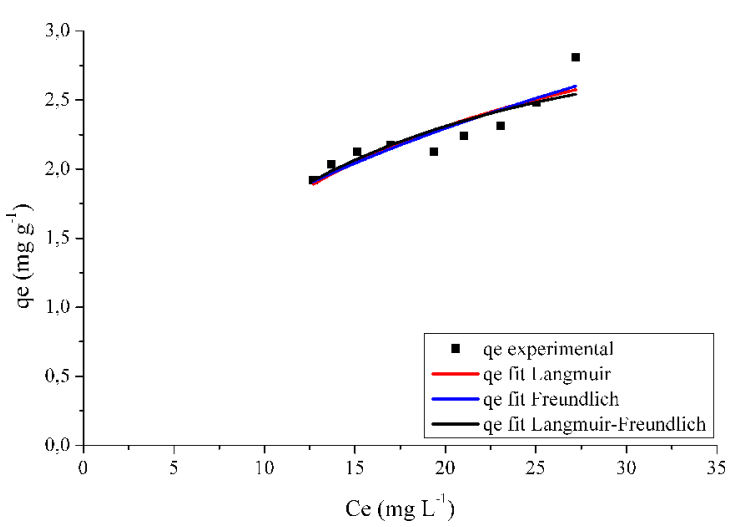

Figure 10. Experimental and predicted adsorption isotherms for tetracycline for the Langmuir, Freundlich and Langmuir-Freundlich models, at temperature of $45^{\circ} \mathrm{C}$.

Table 4 shows the parameters values of the adsorption isotherms obtained by theorical models of Langmuir, Freundlich and Langmuir-Freundlich, adjusted to the experimental data, for the temperatures of $25^{\circ} \mathrm{C}, 35^{\circ} \mathrm{C}$ and $45^{\circ} \mathrm{C}$.

The results of the adjustments shown in Figures 8, 9 and 10 and the parameters values (Table 4), as well the coefficient values of determination $\left(\mathrm{R}^{2}\right)$, indicate that the Freundlich model present the best fit for the three temperatures studied. This result indicates that the adsorption process occurs on heterogeneous, non-specific and energetically non-uniform surfaces, and the formation of mesopores will facilitate the adsorption of larger molecules. The parameter nf of the Freundlich model indicates how the adsorption sites are distributed in terms of their energy and the nf values in the range of 1 to 10 represent a favorable adsorption conditions, which is observed in this work, for the three temperatures studied.

Analyzing the results showed in Table 4 it is verified that the Langmuir-Freundlich model also presented a good fit, with little difference in the values coefficient of determination $\left(\mathrm{R}^{2}\right)$, for the three temperatures studied. It is possible to estimate the maximum adsorption capacity of tetracycline by nanoparticles, which was $14.734 \mathrm{mg} \mathrm{g}^{-1}$, $5.603 \mathrm{mg} \mathrm{g}^{-1}$ and $3.391 \mathrm{mg} \mathrm{g}^{-1}$ for the $25^{\circ} \mathrm{C}, 35^{\circ} \mathrm{C}$ and $45^{\circ} \mathrm{C}$, respectively. It is evident the reduction in the maximum capacity of adsorption with the increase of the temperature of the system, indicating that the tetracycline has greater affinity for the adsorbent when compared to the aqueous phase. This behavior was already expected, since the adsorption process is an exothermic process, being impaired by the increase in temperature ${ }^{66}$.
The Langmuir-Freundlich model has been applied to treat adsorption studies on heterogeneous surfaces, showing an exponential relation between free adsorbate and adsorbed adsorption. Therefore, good tuning of the Langmuir-Freundlich isotherm indicates that $\mathrm{Fe}_{3} \mathrm{O}_{4} @ \mathrm{C}$ nanoparticles are heterogeneous with respect to the adsorption sites, which may be due to the contribution of the adsorption to the adsorption process. The model, when in low concentrations, follows the behavior of the Freundlich model, considering the adsorption in multilayers, whereas in high concentrations it follows the Langmuir model, considering the existence of a saturation point ${ }^{67}$.

Jafari et al. ${ }^{63}$ evaluated the adsorption process of tetracycline using $\mathrm{Fe}_{3} \mathrm{O}_{4}$ nanoparticles coated with activated carbon, with concentrations of tetracycline in the range of 100 to $300 \mathrm{mg} \mathrm{L}^{-1}$. The Langmuir and Freundlich models were applied to describe the process, and the Langmuir model for all concentrations was the best to represents the experimental data. The maximum adsorption capacity obtained was 142.8 $\mathrm{mg} \mathrm{g}^{-1}$ for $300 \mathrm{mg} \mathrm{L}^{-1}$ tetracycline. This value is higher than the one found in this work, possibly due to the fact that the initial concentration is higher and the adsorbent surface is different from the adsorbent used in this work. In the work of Zhang et al. ${ }^{68}$, in which the authors evaluated the adsorption of tetracycline by graphene-coated $\mathrm{Fe}_{3} \mathrm{O}_{4}$ nanoparticle, the Langmuir model presented a better fit, demonstrating that the adsorption process belongs to the monolayer adsorption and the adsorption sites are evenly distributed.

Thermodynamic parameters related to the tetracycline adsorption process were determined from Equations 10 and 11. For the calculation of the thermodynamic parameters, the equilibrium constants found using the LangmuirFreundlich isotherm were used. Table 5 shows the values of the thermodynamic parameters, entropy $(\Delta S)$, enthalpy $(\Delta \mathrm{H})$ and Gibbs free energy $(\Delta \mathrm{G})$.

The positive value of the standard enthalpy indicates the endothermic nature of the tetracycline adsorption process on nanoparticles. The negative value of Gibbs free energy, for the three temperatures studied, confirms the viability and spontaneous nature of the tetracycline adsorption process in nanoparticles. The positive value of the entropy indicates that there is affinity between the tetracycline and the surface of the adsorbent, that is, the positive value of $\Delta \mathrm{S}$ indicates increasing randomness at the solid/liquid interface during the adsorption of tetracycline with time; there is a trend towards greater orderliness of the tetracycline molecules on the adsorbent surface during the formation of stable complexes between tetracycline and the $\mathrm{Fe}_{3} \mathrm{O}_{4} @ \mathrm{C}$ nanoparticles.

Table 5. Thermodynamic parameters, $\Delta \mathrm{S}, \Delta \mathrm{H}$ and $\Delta \mathrm{G}$, of adsorption of tetracycline in the adsorbent $\mathrm{Fe}_{3} \mathrm{O}_{4} @ \mathrm{C}$.

\begin{tabular}{|c|c|c|c|}
\hline Temperature ${ }^{\circ} \mathrm{C}$ & $\Delta \mathrm{S}\left(\mathrm{kJ} \mathrm{mol}^{-1} \mathrm{~K}^{-1}\right)$ & $\Delta \mathrm{H}\left(\mathrm{kJ} \mathrm{mol}^{-1}\right)$ & $-\Delta \mathrm{G}\left(\mathrm{kJ} \mathrm{mol}^{-1}\right)$ \\
\hline 25 & 0.156 & 0.055 & 46,505 \\
\hline 35 & & & 48.066 \\
\hline 45 & & & 49.628 \\
\hline
\end{tabular}




\section{Conclusion}

Hydrothermal co-precipitation methodology proved to be an efficient and viable process for obtaining coreshell nanoparticles of magnetite and carbon. The results obtained by the characterizations indicated the formation of spherical core-shell nanoparticles of $\mathrm{Fe}_{3} \mathrm{O}_{4} @ \mathrm{C}$ with dimensions between 20 to $70 \mathrm{~nm}$, which forms agglomerates with dimensions between 200 to $400 \mathrm{~nm}$.

$\mathrm{Fe}_{3} \mathrm{O}_{4} @ \mathrm{C}$ nanoparticles have good capacity for adsorption of the tetracycline molecules in aqueous medium. The adsorption capacity determined was of $73.3 \%$ when used a concentration of $5 \mathrm{mg} \mathrm{mL}^{-1}$ of core-shell and $30 \mathrm{mg} \mathrm{L}^{-1}$ of tetracycline in aqueous medium.

Adsorption kinetics characteristics obtained for the adsorption by the $\mathrm{Fe}_{3} \mathrm{O}_{4} @ \mathrm{C}$ nanoparticles were well described by the pseudo-second order model and the adsorption mechanisms by the Freundlich and LangmuirFreundlich model. The adjustment of the experimental date by these theorical model establishes as the maximum adsorption capacity of $14.734 \mathrm{mg}$ of tetracycline per gram of $\mathrm{Fe}_{3} \mathrm{O}_{4} @ \mathrm{C}$.

Adsorption process of tetracycline molecules by the $\mathrm{Fe}_{3} \mathrm{O}_{4} @ \mathrm{C}$ nanoparticles is a spontaneous and endothermic dominated by physical adsorption mechanisms. Hence, $\mathrm{Fe}_{3} \mathrm{O}_{4} @ \mathrm{C}$ can be used as an effective sorbent to remove tetracycline molecules in aqueous medium.

\section{Acknowledgment}

The authors are grateful to the UNOCHAPECÓ and CAPES for the financial support and availability of the infrastructure during the research.

\section{References}

1. Zhang Z, Li H, Liu H. Insight into the adsorption of tetracycline onto amino and amino- $\mathrm{Fe}^{3+}$ gunctionalized mesoporous silica: Effect of functionalized groups. Journal of Environmental Sciences. 2018;65:171-178.

2. Ahmadi M, Motlagh HR, Jaafarzadeh N, Mostoufi A, Saeedi R, Barzegar G, et al. Enhanced photocatalytic degradation of tetracycline and real pharmaceutical wastewater using MWCNT/ $\mathrm{TiO}_{2}$ nano-composite. Journal of Environmental Management. 2017;186(Pt 1):55-63.

3. Khodadadi M, Ehrampoush MH, Ghaneian MT, Allahresani A, Mahvi AH. Synthesis and characterizations of $\mathrm{FeNi}_{3} @ \mathrm{SiO}_{2} @$ $\mathrm{TiO}_{2}$ nanocomposite and its application in photo- catalytic degradation of tetracycline in simulated wastewater. Journal of Molecular Liquids. 2018;255:224-232.

4. Sayğılı H, Güzel F. Effective removal of tetracycline from aqueous solution using activated carbon prepared from tomato (Lycopersicon esculentum Mill.) industrial processing waste. Ecotoxicology and Environmental Safety. 2016;131:22-29.
5. Chen Y, Wang F, Duan L, Yang H, Gao J. Tetracycline adsorption onto rice husk ash, an agricultural waste: Its kinetic and thermodynamic studies. Journal of Molecular Liquids. 2016;222:487-494.

6. Lv JM, Ma YL, Chang X, Fan SB. Removal and removing mechanism of tetracycline residue from aqueous solution by using Cu-13X. Chemical Engineering Journal. 2015;273:247-253.

7. Chu Y, Fang C, Wang H, Wu X, Gu Y, Shu J. Effects of anaerobic composting on tetracycline degradation in swine manure. Chinese Journal of Chemical Engineering. 2017;25(10):1505-1511.

8. Xiong W, Zeng G, Yang Z, Zhou Y, Zhang C, Cheng M, et al. Adsorption of tetracycline antibiotics from aqueous solutions on nanocomposite multi-walled carbon nanotube functionalized MIL-53(Fe) as new adsorbent. Science of the Total Environment. 2018;627:235-244.

9. Álvarez-Torrellas S, Rodríguez A, Ovejero G, García J. Comparative adsorption performance of ibuprofen and tetracycline from aqueous solution by carbonaceous materials. Chemical Engineering Journal. 2016;283:936-947.

10. Li N, Yang S, Chen J, Gao J, He H, Sun C. Electro-adsorption of tetracycline from aqueous solution bycarbonized pomelo peel and composite with aniline. Applied Surface Science. 2016;386:460-466.

11. Li Y, Wang S, Zhang Y, Han R, Wei W. Enhanced tetracycline adsorption onto hydroxyapatite by $\mathrm{Fe}(\mathrm{III})$ incorporation. Journal of Molecular Liquids. 2017;247:171-181.

12. Cao J, Xiong Z, Lai B. Effect of initial $\mathrm{pH}$ on the tetracycline (TC) removal by zero-valent iron: Adsorption, oxidation and reduction. Chemical Engineering Journal. 2018;343:492-499.

13. Marzbali MH, Esmaieli M, Abolghasemi H, Marzbali MH. Tetracycline adsorption by $\mathrm{H}_{3} \mathrm{PO}_{4}$-activated carbon produced from apricot nut shells: A batch study. Process Safety and Environmental Protection. 2016;102:700-709.

14. Fernández R, Ruiz AI, García-Delgado C, González-Santamaría DE, Antón-Herrero R, Yunta F, et al. Stevensite-based geofilter for the retention of tetracycline from water. Science of The Total Environment. 2018;645:146-155.

15. Soltani RDC, Mashayekhi M, Jorfi S, Khataee A, Ghanadzadeh MJ, Sillanpää M. Implementation of martite nanoparticles prepared through planetary ball milling as a heterogeneous activator of oxone for degradation of tetracycline antibiotic: Ultrasound and peroxy-enhancement. Chemosphere. 2018;210:699-708.

16. Ahmed MJ. Adsorption of quinolone, tetracycline, and penicillin antibiotics from aqueous solution using activated carbons: Review. Environmental Toxicology and Pharmacology. 2017;50:1-10.

17. Okoli CP, Ofomaja AE. Degree of time dependency of kinetic coefficient as a function of adsorbate concentration; new insights from adsorption of tetracycline onto monodispersed starchstabilized magnetic nanocomposite. Journal of Environmental Management. 2018;218:139-147.

18. Yu B, Bai Y, Ming Z, Yang H, Chen L, Hu X, et al. Adsorption behaviors of tetracycline on magnetic graphene oxide sponge. Materials Chemistry and Physics. 2017;198:283-290. 
19. Ou J, Mei M, Xu X. Magnetic adsorbent constructed from the loading of amino functionalized $\mathrm{Fe}_{3} \mathrm{O}_{4}$ on coordination complex modified polyoxometalates nanoparticle and its tetracycline adsorption removal property study. Journal of Solid State Chemistry. 2016;238:182-188.

20. Harja M, Ciobanu G. Studies on adsorption of oxytetracycline from aqueous solutions onto hydroxyapatite. Science of The Total Environment. 2018;628-629:36-43.

21. Caponi N, Collazzo GC, Jahn SL, Dotto GL, Mazutti MA, Foletto EL. Use of Brazilian Kaolin as a Potential Low-cost Adsorbent for the Removal of Malachite Green from Colored Effluents. Materials Research. 2017;20(Suppl 2):14-22.

22. Morcali MH, Zeytuncu B, Yucel O. Platinum uptake from chloride solutions using biosorbents. Materials Research. 2013;16(2):528-538.

23. Sarkar T, Tiwari S, Rawat K, Solanki PR, Bohidar HB. Hydrophilic, fluorescent and superparamagnetic iron oxide-carbon composite nanoparticles. Colloids and Surfaces A: Physicochemical and Engineering Aspects. 2017;514:218-225.

24. Lobato NCC, Mansur MB, Ferreira AM. Characterization and Chemical Stability of Hydrophilic and Hydrophobic Magnetic Nanoparticles. Materials Research. 2017;20(3):736-746.

25. Salviano LB, Cardoso TMS, Silva GC, Dantas MSS, Ferreira AM. Microstructural Assessment of Magnetite Nanoparticles $\left(\mathrm{Fe}_{3} \mathrm{O}_{4}\right)$ Obtained by Chemical Precipitation Under Different Synthesis Conditions. Materials Research. 2018;21(2):e20170764.

26. Wu R, Liu JH, Zhao L, Zhang X, Xie J, Yu B, et al. Hydrothermal preparation of magnetic $\mathrm{Fe}_{3} \mathrm{O}_{4} @ \mathrm{C}$ nanoparticles for dye adsorption. Journal of Environmental Chemical Engineering. 2014;2(2):907-913.

27. Bao X, Qiang Z, Chang JH, Ben W, Qu J. Synthesis of carboncoated magnetic nanocomposite $\left(\mathrm{Fe}_{3} \mathrm{O}_{4} @ \mathrm{C}\right)$ and its application for sulfonamide antibiotics removal from water. Journal of Environmental Sciences. 2014;26(5):962-969.

28. Huong PTL, Huy LT, Lan H, Thang LH, An TT, Quy NV, et al. Magnetic iron oxide-carbon nanocomposites: Impacts of carbon coating on the $\mathrm{As}(\mathrm{V})$ adsorption and inductive heating responses. Journal of Alloys and Compounds. 2018;739:139-148.

29. Konicki W, Hełminiak A, Arabczyk W, Mijowska E. Adsorption of cationic dyes onto Fe@graphite core-shell magnetic nanocomposite: Equilibrium, kinetics and thermodynamics. Chemical Engineering Research and Design. 2018;129:259-270.

30. Lima MM, Gonçalves JPZ, Soares C, Riella HG, Fernandes SC, Fiori MA, et al. Iron-Carbon Core-Shell Nanoparticles Obtained with Different Conditions of Synthesis. Materials Science Forum. 2017;899:221-226.

31. Rietveld HM. The Crystal Structure of some Alkaline Earth Metal Uranates of the Type $\mathrm{M}_{3} \mathrm{UO}_{6}$. Acta Crystallographica. 1966;20:508-513.

32. Brunauer S, Emmett PH, Teller E. Adsorption of Gases in Multimolecular Layers. Journal of the American Chemical Society. 1938;60(2):309-319.
33. ASTM International. ASTM D6556-17 - Standard Test Method for Carbon Black-Total and External Surface Area by Nitrogen Adsorption. West Conshohocken: ASTM International; 2017. DOI: https://doi.org/10.1520/D6556-17

34. Babić BM, Milonjić SK, Polovina MJ, Kaludierović BV. Point of zero charge and intrinsic equilibrium constants of activated carbon cloth. Carbon. 1999;37(3):477-481.

35. Regalbuto JR, Robles J. The Engineering of Pt/Carbon Catalyst Preparation. Chicago: University of Illinois; 2004.

36. Zhang C, Mo Z, Zhang P, Feng C, Guo R. Facile synthesis of porous carbon@ $\mathrm{Fe}_{3} \mathrm{O}_{4}$ composites and their applications in wastewater treatment. Materials Letters. 2013;106:107-110.

37. Ahmadian-Fard-Fini S, Salavati-Niasari M, Ghanbari D. Hydrothermal green synthesis of magnetic $\mathrm{Fe}_{3} \mathrm{O}_{4}$-carbon dots by lemon and grape fruit extracts and as a photoluminescence sensor for detecting of E. coli bacteria. Spectrochimica Acta Part A: Molecular and Biomolecular Spectroscopy. 2018;203:481-493

38. Rostami-Vartooni A, Moradi-Saadatmand A, Mahdavi M. Catalytic reduction of organic pollutants using biosynthesized $\mathrm{Ag} / \mathrm{C} / \mathrm{Fe}_{3} \mathrm{O}_{4}$ nanocomposite by red water and Caesalpinia gilliesii flower extract. Materials Chemistry and Physics. 2018;219:328-339.

39. Zarei S, Niad M, Raanaei H. The removal of mercury ion pollution by using $\mathrm{Fe}_{3} \mathrm{O}_{4}$-nanocellulose: Synthesis, characterizations and DFT studies. Journal of Hazardous Materials. 2018;344:258-273.

40. Asoufi HM, Al-Antary TM, Awwad AM. Green route for synthesis hematite $\left(\alpha-\mathrm{Fe}_{2} \mathrm{O}_{3}\right)$ nanoparticles: Toxicity effect on the green peach aphid, Myzus persicae (Sulzer). Environmental Nanotechnology, Monitoring \& Management. 2018;9:107-111.

41. Ali M, Tehseen U, Ali M, Ali L, Mumtaz M. Study of uncoated and silica-coated hematite $\left(\alpha-\mathrm{Fe}_{2} \mathrm{O}_{3}\right)$ nanoparticles. Surfaces and Interfaces. 2018;13:196-204.

42. Leostean C, Pana O, Stefan M, Popa A, Toloman D, Senila M, et al. New properties of $\mathrm{Fe}_{3} \mathrm{O}_{4} @ \mathrm{SnO}_{2}$ core shell nanoparticles following interface charge/spin transfer. Applied Surface Science. 2018;427(Pt A):192-201.

43. Madhubala V, Kalaivani T. Phyto and hydrothermal synthesis of $\mathrm{Fe}_{3} \mathrm{O}_{4} @ \mathrm{ZnO}$ core-shell nanoparticles using Azadirachta indica and its cytotoxicity studies. Applied Surface Science. 2018;449:584-590.

44. Wan X, Zhan Y, Long Z, Zeng G, He Y. Core@double-shell structured magnetic halloysite nanotube nano-hybrid as efficient recyclable adsorbent for methylene blue removal. Chemical Engineering Journal. 2017;330:491-504.

45. Cheng Y, Zhao H, Yang Z, Lv J, Cao J, Qi X, et al. An unusual route to grow carbon shell on $\mathrm{Fe}_{3} \mathrm{O}_{4}$ microspheres with enhanced microwave absorption. Journal of Alloys and Compounds. 2018;762:463-472.

46. Vezzù K, Delpeuch AB, Negro E, Polizzi S, Nawn G, Bertasi F, et al. Fe-carbon nitride "Core-shell" electrocatalysts for the oxygen reduction reaction. Electrochimica Acta. 2016;222:1778-1791.

47. Kubániová D, Kubíčková L, Kmječ T, Závěta K, Nižňanský D, Brázda P, et al. Hematite: Morin temperature of nanoparticles with different size. Journal of Magnetism and Magnetic Materials. 2019;475:611-619. 
48. Li W, Wang Q, Feng X, Tan W, Zheng L, Yin H, et al. The distinct effects of isomorphous substitution of various divalence trace metals on hematite structure. Materials Chemistry and Physics. 2018;217:40-47.

49. Ashrafi A, Rahbar-Kelishami A, Shayesteh H. Highly efficient simultaneous ultrasonic assisted adsorption of $\mathrm{Pb}$ (II) by $\mathrm{Fe}_{3} \mathrm{O}_{4} @ \mathrm{MnO}_{2}$ core-shell magnetic nanoparticles: Synthesis and characterization, kinetic, equilibrium, and thermodynamic studies. Journal of Molecular Structure. 2017;1147:40-47.

50. Angamuthu M, Satishkumar G, Landau MV. Precisely controlled encapsulation of $\mathrm{Fe}_{3} \mathrm{O}_{4}$ nanoparticles in mesoporous carbon nanodisk using iron based MOF precursor for effective dye removal. Microporous and Mesoporous Materials. 2017;251:58-68.

51. Petcharoen K, Sirivat A. Dual responses of magnetite-graphene hybrid in polyurethane under magnetic and electric stimuli. Sensors and Actuators A: Physical. 2016;251:26-34.

52. Konicki W, Hełminiak A, Arabczyk W, Mijowska E. Adsorption of cationic dyes onto Fe@graphite core-shell magnetic nanocomposite: Equilibrium, kinetics and thermodynamics. Chemical Engineering Research and Design. 2018;129:259-270.

53. Wu T, Liu Y, Zeng X, Cui T, Zhao Y, Li Y, et al. Facile Hydrothermal Synthesis of $\mathrm{Fe}_{3} \mathrm{O}_{4} / \mathrm{C}$ Core-Shell Nanorings for Efficient Low-Frequency Microwave Absorption. ACS Applied Materials \& Interfaces. 2016;8(11):7370-7380.

54. Zhong Y, Zhou X, Li X, Zhang S, Liu Y, Yu X, et al. Sandwich-like mesoporous graphene@magnetite@carbon nanosheets for highrate lithium ion batteries. Solid State Sciences. 2016;57:16-23.

55. Sayahi H, Mohsenzadeh F, Darabi HR, Aghapoor K. Facile and economical fabrication of magnetite/graphite nanocomposites for supercapacitor electrodes with significantly extended potential window. Journal of Alloys and Compounds. 2019;778:633-642.

56. Bayazit ŞS, Kerkez Ö. Hexavalent chromium adsorption on superparamagnetic multi-wall carbon nanotubes and activated carbon composites. Chemical Engineering Research and Design. 2014;92(11):2725-2733.

57. Čerović LS, Milonjić SK, Todorović MB, Trtanj MI, Pogozhev YS, Blagoveschenskii Y, et al. Point of zero charge of different carbides. Colloids and Surfaces A: Physicochemical and Engineering Aspects. 2007;297(1-3):1-6.
58. Chang PH, Jiang WT, Li Z, Jean JS, Kuo CY. Antibiotic tetracycline in the environments - a review. Research \& Reviews: Journal of Pharmaceutical Analysis. 2015;4(3):86-111.

59. Vidal CB, Raulino GSC, Barros AL, Lima ACA, Ribeiro JP, Pires MJR, et al. BTEX removal from aqueous solutions by HDTMA-modified Y zeolite. Journal of Environmental Management. 2012;112:178-185.

60. Orlandi G, Cavasotto J, Machado Junior FRS, Colpani GL, Dal Magro J, Dalcanton F, et al. An adsorbent with a high adsorption capacity obtained from the cellulose sludge of industrial residues. Chemosphere. 2017;169:171-180.

61. Beck RE, Schultz JS. Hindered diffusion in microporous membranes with known pore geometry. Science. 1970;170(3964):1302-1305.

62. Lv Y, Li P, Che Y, Hu C, Ran S, Shi P, et al. Facile Preparation and Characterization of Nanostructured BiOI microspheres with certain adsorption-photocatalytic properties. Materials Research. 2018;21(3):e20170705.

63. Jafari AJ, Kakavandi B, Jaafarzadeh N, Kalantary RR, Ahmadi M, Babaei AA. Fenton-like catalytic oxidation of tetracycline by $\mathrm{AC} @ \mathrm{Fe}_{3} \mathrm{O}_{4}$ as a heterogeneous persulfate activator: adsorption and degradation studies. Journal of Industrial and Engineering Chemistry. 2017;45:323-333.

64. Lin AYC, Tsai YT. Occurrence of pharmaceuticals in Taiwan's surface waters: impact of waste streams from hospitals and pharmaceutical production facilities. Science of The Total Environment. 2009;407(12):3793-3802.

65. Liu M, Hou LA, Yu S, Xi B, Zhao Y, Xia X. MCM-41 impregnated with A zeolite precursor: Synthesis, characterization and tetracycline antibiotics removal from aqueous solution. Chemical Engineering Journal. 2013;223:678-687.

66. Cantuaria ML. Remoção de prata iônica monovalente por adsorção em argila bentonítica. [Dissertation]. Campinas: State University of Campinas, Chemical Engineering Department; 2014. 109 p.

67. Praus P, Turicová M. A physico-chemical study of the cationic surfactants adsorption on montmorillonite. Journal of the Brazilian Chemical Society. 2007;18(2):378-383.

68. Zhang Y, Jiao Z, Hu Y, Lv S, Fan H, Zeng Y, et al. Removal of tetracycline and oxytetracycline from water by magnetic $\mathrm{Fe}_{3} \mathrm{O}_{4} @$ graphene. Environmental Science and Pollution Research. 2017;24(3):2987-2995. 